\title{
Association between Periodontitis and Myocardial Infarction: Systematic Review and Meta-Analysis
}

\author{
Luiz Carlos Bodanese, ${ }^{(0)}$ Gabriel Campos Louzeiro, ${ }^{(0)}$ Gabriela Agne Magnus, ${ }^{(\mathbb{1}}$ Ângela Hamann Baptista, \\ Fernanda Gonçalves Salum, ${ }^{\circledR}$ Rita Mattiello ${ }^{\circledR}$ \\ Pontifícia Universidade Católica do Rio Grande do Sul (PUCRS), Porto Alegre, RS - Brazil
}

\section{Abstract}

The association between periodontitis and myocardial infarction remains unclear in the literature. Few studies have addressed periodontitis exposure as a predisposing factor for the development of myocardial infarction. Therefore, the present systematic review aims to analyze the association between periodontitis and myocardial infarction. This meta-analysis systematically searched MEDLINE, EMBASE, The Cochrane Controlled Trials Register, SCIELO, LILACS, CINAHL, Scopus, Web of Science and grey literature for studies estimating the association between periodontitis and myocardial infarction. Quality of evidence was assessed for all studies. The meta-analysis was conducted using random-effects models. Four of the six studies selected were included in the meta-analysis, including 1,035,703 subjects. The association between periodontitis and myocardial infarction was: RR: 5.99 (95\% CI: $1.17-30.68)$, but with high heterogeneity $\left(\mathrm{I}^{2}=100 \%\right.$; $\mathrm{p}<0.01)$. The results including only the highest quality articles, was lower: RR: 2.62 (95\% CI: 1.47-4.70 3.83), but with lower heterogeneity $\left(\mathrm{I}^{2}=85.5 \%\right.$; $\left.\mathrm{p}<0.01\right)$. The present systematic review with meta-analysis showed an association between periodontitis and acute myocardial infarction, but with a high level of heterogeneity.

\section{Keywords}

Cardiovascular Diseases/mortality; Periodontitis/ complications; Pulpitis, Myocardial Infarction/complications; Atherosclerosis/complications. Lipoproteins/analysis; Atherosclerosis/complications; Inflammation; MetaAnalysis.

\section{Introduction}

Cardiovascular diseases (CVDs) are the leading causes of death in the world, with an annual mortality of 17.9 million people. ${ }^{1}$ Atherosclerotic disease is the most prevalent CVD, characterized by chronic inflammation mediated by the accumulation of lipoproteins in the arteries, which can cause chronic coronary disease and myocardial infarction (MI). ${ }^{2}$ Several risk factors predispose to this condition, notably the genetic determinism, smoking habit, physical inactivity, high body mass index, hypertension, dyslipidemia and diabetes. ${ }^{3}$ Poor oral health status, especially periodontal conditions, such as periodontitis, has also been reported as a potential aggravating factor for CVD. ${ }^{4}$

The latest consensus of the American Academy of Periodontology (AAP) and the European Federation of Periodontology (EFP) states that periodontitis is characterized by an "inflammation mediated by the host associated with microorganisms that results in loss of periodontal insertion". ${ }^{5}$ It is a chronic, non-curable disease associated with many strains of bacteria, especially gram-negative ones. ${ }^{5}$ There is evidence that oral pathogenic bacteria can cause bacteremia, increased expression of pro-inflammatory proteins (e.g. IL-1, IL-6, IL-8, TNF and of C-reactive protein), leading to vascular infection and development of CVD. ${ }^{6,7}$

As with CVD, periodontitis is more prevalent in adults. A Brazilian epidemiological survey ${ }^{8}$ showed that about $19.4 \%$ of adults between the ages of 35 and 44 years, and approximately $3.3 \%$ of elderly between 65-74 years old have some degree of periodontal disease. The lower prevalence in the elderly is justified

Mailing Address: Luiz Carlos Bodanese

Av. Ipiranga, 6690, cj. 402. Postal Code: 90610-000, Porto Alegre, RS - Brazil.

E-mail: Icbodanese@pucrs.br 
by the greater number of missing teeth for long exposure to oral diseases. Although there is sufficient evidence to support the relationship between CVD and periodontitis, ${ }^{9}$ the association between periodontitis and MI remains unclear in the literature. Most studies have shown the increase of the prevalence of periodontitis in infarcted patients, suggesting a strong association between this condition and the acute ischemic event ${ }^{10-12}$. However, few of these studies have addressed periodontitis as a predisposing factor for the development of MI. Thus, the present systematic review aimed to analyze the association between periodontitis and $\mathrm{MI}$.

\section{Methods}

This systematic review and meta-analysis were performed following the PRISMA guidelines, and its protocol was registered in the PROSPERO database (CRD42016052902).

\section{Eligibility criteria}

The inclusion criteria for studies were the following: (i) use of periodontitis as exposure factor and MI as outcome; (ii) observational studies (of all types). There was no language restriction. Case studies, review studies, case series, experimental models, response letters, editorials and duplicated publications were excluded Duplicate studies were those published by the same study group, with the same inclusion date and population characteristics. In case of duplicate studies, the study with the larger sample size was considered for analysis.

\section{Information sources}

The following databases were used in the literature search, from inception to October 2018: MEDLINE (via PUBMED), EMBASE, Cochrane The Cochrane Controlled Trials Register (CCTR), Latin American Caribbean Health Sciences Literature (LILACS via BIREME), Cumulative Index to Nursing and Allied Health Literature (via EBSCOhost), Scopus and Web of Science (Thomson Reuters). The MEDLINE search strategy was adapted to the other databases.

\section{Study selection and data extraction}

Two authors independently screened the abstracts and titles of the studies retrieved. Full texts of all potentially relevant articles were then analyzed. In both phases, in case of disagreement between the researchers, a third independent researcher was involved to achieve final consensus. For studies that fulfilled the inclusion criteria, three authors worked in the data extraction process. The agreement between the authors, estimated by the Kappa coefficient, was considered good $(\mathrm{k}=0.735)$.

The following data were extracted from the articles selected: identification (authors and year of publication), general characteristics of participants (including age and gender), sample size, time of observation, definition of MI and periodontitis, magnitude of exposure and effect size.

\section{Risk of bias}

The association between exposure and outcome was synthesized from a meta-analysis using estimated risk calculations.

Risk of bias was analyzed using the NIH Quality Assessment Tool for Observational Cohort and CrossSectional Studies. ${ }^{13}$ This tool allows the assessment of the risk of bias and the quality of the study, and classified them as "good", "fair" or "bad". "Good" quality was attributed to studies that adopted at least eight of the established criteria. The biases were assessed by two evaluators and, in case of disagreement, a third evaluator was involved.

\section{Statistical analysis}

The association between periodontitis and MI was analyzed using meta-analysis with random-effects models. The heterogeneity among studies was assessed using the Q-Cochran test and $\mathrm{I}^{2}$ statistics. We planned to explore heterogeneity using race as a factor, but the studies did not provide sufficient data. For longitudinal and clinical trials that assessed phase angle in more than one moment, the baseline values were considered for analysis. The authors of the present review were aware that some of issues suitable for sensitivity analysis were only identified during the review process, when the characteristics of each study were identified. At this phase of our review, we performed a sensitivity analysis to assess the robustness of our analyses by including only good-quality studies with good quality. The metaanalysis was performed using the Meta $\mathrm{R}$ package (https://CRAN.R-project.org/package\&\#61;meta). 


\section{Results}

A total of 3,384 articles were retrieved from the selected databases. Of these, 1,272 duplicate articles were excluded. After reading the titles and abstracts, 2,013 articles were excluded according to the exclusion criteria. Of the 99 articles selected for full reading, 93 were excluded, of which 75 did not utilize periodontitis as exposure and/or MI as outcome, 12 articles were not available, one analyzed periodontitis treatment, three were letters to editor, and two were in vitro studies (Figure 1).

\section{Characteristics of the included studies}

Of the six articles included in qualitative analysis, the studies of Noguchi et al., ${ }^{14}$, Lee et al., ${ }^{15}$ Hansen et al. ${ }^{16}$ and Holmlund et al. ${ }^{17}$ were cohort studies, one retrospective ${ }^{15}$ and three prospective studies ${ }^{14,16,17}$ and the studies by Arbes et al., ${ }^{10}$ and Holmlund et al. ${ }^{18}$ were cross-sectional studies. The shortest observation period was 5 years $^{14}$ and the largest was 34 years. ${ }^{17}$ The sample size of the studies ranged from $3,081^{14}$ to $1,025,340$ participants, ${ }^{15}$ and their ages ranged from $1^{15}$ to $85^{17}$ years, with two studies without maximum age restriction. ${ }^{10.16}$ Except for the study by Noguchi et al., ${ }^{14}$ who included only men in their sample, the other studies did not show gender restriction. No study used 'previous diseases' as inclusion criteria. Data extracted from the selected studies are described in Table 1. Data regarding the number of outcomes and estimated risks of the six studies included in the qualitative analysis are available in Table 2.

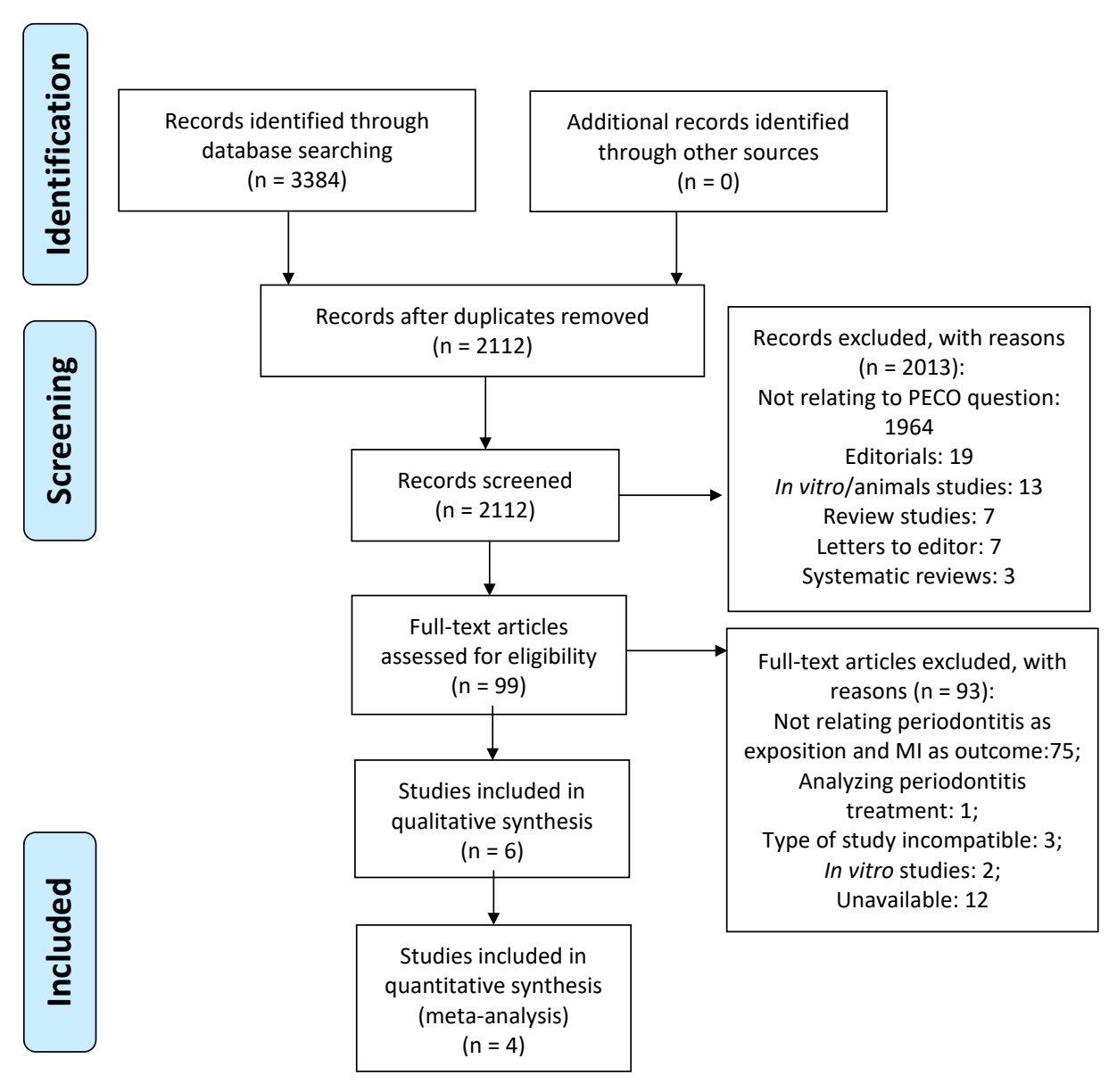

Figure 1 - Flowchart of the study selection process MI: myocardial infarction

From: Moher D, Liberati A, Tetzlaff J, Altman DG, The PRISMA Group (2009). Preferred Reporting Items for Systematic Reviews and Meta-Analyses: The PRISMA Statement. PLoS Med 6(7): e1000097. doi:10.1371/journal.pmed1000097

For more information, visit www.prisma-statement.org. 
Table 1 - General characteristics of the studies

\begin{tabular}{|c|c|c|c|c|c|c|c|}
\hline Author, year & population & $\mathbf{n}$ & $\begin{array}{l}\text { Age } \\
\text { (Years) }\end{array}$ & Gender & $\begin{array}{c}\text { Design and } \\
\text { observation } \\
\text { time }\end{array}$ & Definition of mi & $\begin{array}{l}\text { Definition of } \\
\text { periodontitis }\end{array}$ \\
\hline $\begin{array}{l}\text { Arbes et al., } \\
(1999)^{10}\end{array}$ & $\begin{array}{l}\text { NHANES } \\
\text { III* data of } \\
\text { United States } \\
\text { population } \\
\text { sample }\end{array}$ & 5564 & $\geq 40$ & $\begin{array}{c}\text { 2,757 men } \\
\text { 2,807 } \\
\text { women }\end{array}$ & $\begin{array}{l}\text { Cross- } \\
\text { sectional } \\
\text { study }\end{array}$ & $\begin{array}{l}\text { Self-reported heart } \\
\text { attack }\end{array}$ & $\begin{array}{c}\text { Clinical attachmen } \\
\text { loss } \geq 3 \mathrm{~mm}\end{array}$ \\
\hline $\begin{array}{l}\text { HOLMLUNet } \\
\text { al., (2006) }{ }^{17-18}\end{array}$ & $\begin{array}{c}\text { Patients } \\
\text { from the } \\
\text { Department of } \\
\text { Periodontology, } \\
\text { Gävle County } \\
\text { Hospital }\end{array}$ & 4.254 & $20-70$ & $\begin{array}{c}\text { 1,866 men } \\
\text { 2,388 } \\
\text { women }\end{array}$ & $\begin{array}{l}\text { Cross- } \\
\text { sectional } \\
\text { study }\end{array}$ & $\begin{array}{l}\text { Self-reported heart } \\
\text { attack }\end{array}$ & Bone loss $>2 \mathrm{~mm}$ \\
\hline
\end{tabular}

\begin{tabular}{|c|c|c|c|c|c|c|c|}
\hline $\begin{array}{l}\text { NOGUCHI } \\
\text { ET AL., } \\
(2014)^{14}\end{array}$ & $\begin{array}{c}\text { Employees } \\
\text { of a financial } \\
\text { company in } \\
\text { Japan }\end{array}$ & 3081 & $36-59$ & Only men & $\begin{array}{c}\text { Prospective } \\
\text { cohort } \\
\text { between } 2004 \\
\text { - } 2009\end{array}$ & $\begin{array}{l}\text { Patients report } \\
\text { that they were } \\
\text { undergoing } \\
\text { myocardial } \\
\text { infarction } \\
\text { treatment }\end{array}$ & $\begin{array}{l}\text { Self-administered } \\
\text { questionnaire } \\
\text { produced by the } \\
\text { authors. }\end{array}$ \\
\hline
\end{tabular}

\begin{tabular}{|c|c|c|c|c|c|c|c|}
\hline $\begin{array}{l}\text { LEE et al., } \\
(2015)^{15}\end{array}$ & $\begin{array}{c}\text { Random sample } \\
\text { (2\% of total) of } \\
\text { South Korean } \\
\text { population } \\
\text { covered by } \\
\text { National Health } \\
\text { Insurance }\end{array}$ & 1.025 .340 & $1-79$ & $\begin{array}{c}513,258 \\
\text { men } \\
512,082 \\
\text { women }\end{array}$ & $\begin{array}{c}\text { Retrospective } \\
\text { cohort } \\
\text { between } 2002 \\
\text { a } 2013\end{array}$ & $\begin{array}{l}\text { Records of the } \\
\text { 6th ed. Korean } \\
\text { Classification of } \\
\text { Diseases (KCD-6): } \\
\text { Code not specified }\end{array}$ & $\begin{array}{c}\text { Records of the } \\
\text { 6th ed. Korean } \\
\text { Classification of } \\
\text { Diseases (KCD-6): } \\
\text { K052 - K056 }\end{array}$ \\
\hline $\begin{array}{l}\text { HANSEN et } \\
\text { al., (2016) }{ }^{16}\end{array}$ & $\begin{array}{l}\text { Sample of } \\
\text { the Danish } \\
\text { population from } \\
\text { the National } \\
\text { Patient Registry }\end{array}$ & 100.694 & $\geq 18$ & $\begin{array}{c}\text { 57,421 men } \\
43,273 \\
\text { women }\end{array}$ & $\begin{array}{c}\text { Prospective } \\
\text { cohort } \\
\text { between } \\
\text { 1997- } 2011\end{array}$ & $\begin{array}{c}\text { International } \\
\text { Classification of } \\
\text { Diseases (ICD-10) } \\
\text { Records: Codes } \\
\text { I21-I22 }\end{array}$ & $\begin{array}{c}\text { International } \\
\text { Classification of } \\
\text { Diseases (ICD-08) } \\
\text { Records: Code } \\
523.49 \text { and } 523.49 \\
\text { International } \\
\text { Classification of } \\
\text { Diseases (ICD-10) } \\
\text { Records: Code } \\
\text { K05.2 - 05.3. }\end{array}$ \\
\hline $\begin{array}{l}\text { HOLMLUNet } \\
\text { al. }(2017)^{17-18}\end{array}$ & $\begin{array}{l}\text { Patients } \\
\text { from the } \\
\text { Department of } \\
\text { Periodontology, } \\
\text { Gävle County } \\
\text { Hospital }\end{array}$ & 8.999 & $20-85$ & $\begin{array}{c}\text { 3,870 men } \\
5,129 \\
\text { women }\end{array}$ & $\begin{array}{c}\text { Prospective } \\
\text { cohort } \\
\text { between } 1979 \\
-2013\end{array}$ & $\begin{array}{c}\text { International } \\
\text { Classification of } \\
\text { Disease Records: } \\
421 \text { (ICD-8 and } \\
\text { ICD-9) and I21 } \\
\text { (ICD-10) }\end{array}$ & $\begin{array}{c}\text { Probing depth } \geq \\
4 \mathrm{~mm}\end{array}$ \\
\hline
\end{tabular}

\section{Meta-analysis}

The association of MI in patients with periodontitis was calculated using data retrieved from four studies ${ }^{10,14,15,18}$ including $1,035,703$ subjects. The result of this analysis was - RR: 5.99 (95\% CI: 1.17-30.68), but with a high heterogeneity $\left(\mathrm{I}^{2}=100 \% ; \mathrm{p}<0.01\right)$. Result of the analysis including only the highest-quality articles was lower - RR: 2.62 (95\% CI: 1.47-4.70 3.83), with a lower heterogeneity also $\left(\mathrm{I}^{2}=85.5 \%\right.$; $\left.\mathrm{p}<0.01\right)$ (Figure 2). 
Table 2 - Results of risk analysis between periodontitis and AMI found in the studies

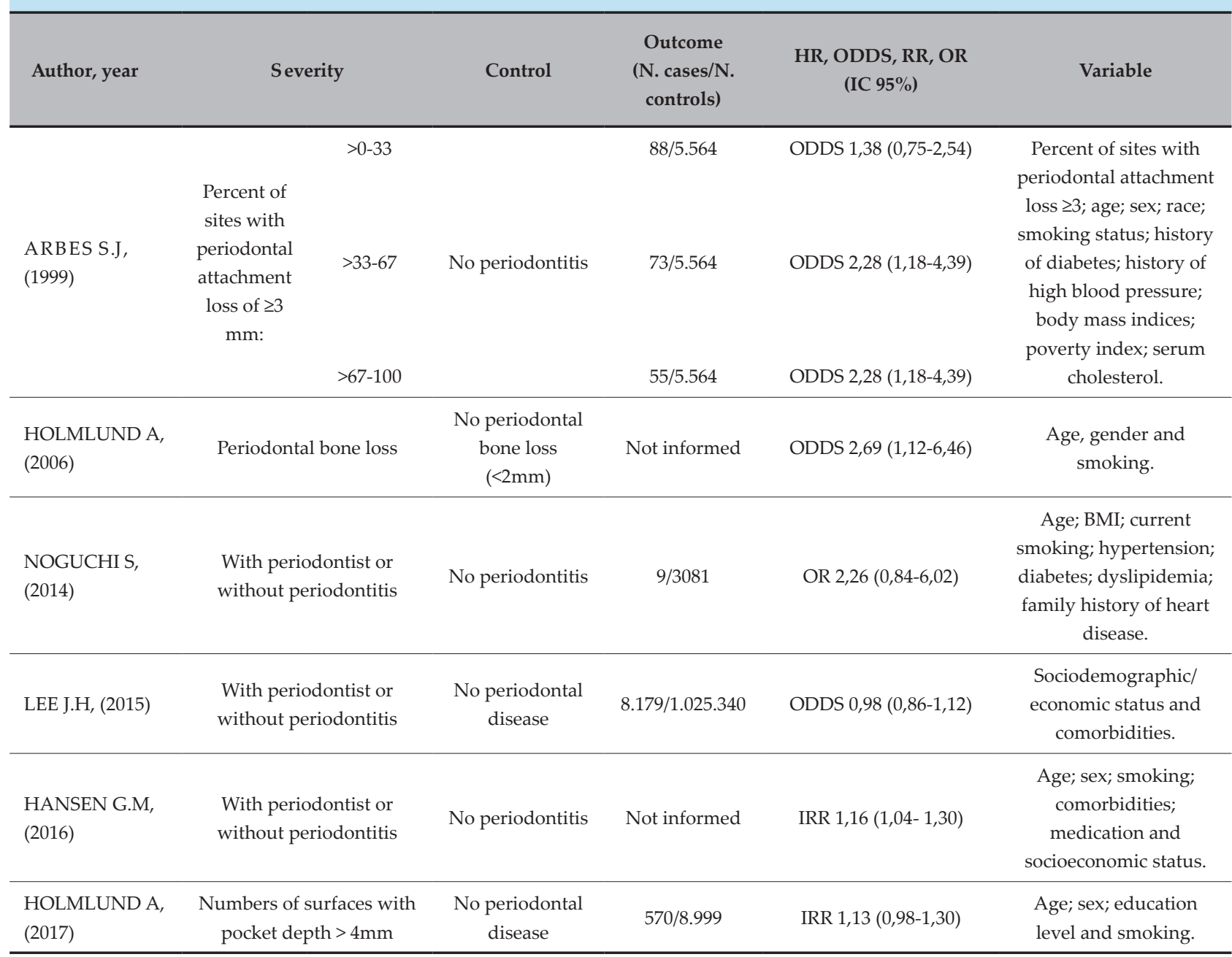

\begin{tabular}{|c|c|c|c|c|}
\hline \multirow[b]{2}{*}{ Study } & \multicolumn{2}{|c|}{ Experimental } & \multicolumn{2}{|c|}{ Control } \\
\hline & Events & Total & Events & Total \\
\hline Arbes S.J, 1999 & 216 & 3818 & 28 & 1746 \\
\hline Noguchi S, 2014 & 9 & 739 & 8 & 2342 \\
\hline Lee J.H, 2015 & 3660 & 321103 & 4519 & 704237 \\
\hline $\begin{array}{l}\text { Random effects model } \\
\text { Heterogeneity } t^{2}=86 \%, \tau^{2}\end{array}$ & $2=0.2025$ & $\begin{array}{l}325660 \\
p<0.01\end{array}$ & & 708325 \\
\hline
\end{tabular}

Figure 2 - Meta-analysis of high-quality studies on the association of acute myocardial infarction with periodontitis

\section{Risk of bias}

The quality of the included studies was considered reasonable. All of them described adequately the purposes and the population of the study, and evaluated periodontitis prior to the development of MI. Only in one study $(16.67 \%)^{18}$ the participation rate was less than $50 \%$ of the population. No study described the sample calculation in detail, blinded the periodontitis assessment 
or performed periodontitis measurement more than once over time. The follow-up time described was considered good in four $(66.7 \%)$ of the studies. ${ }^{14-17}$ In only three ${ }^{10,14,18}$ (50.0\%) studies patients were classified according to the degree of periodontitis. Misdiagnosis and/or validation of the diagnosis of acute MI were found in all studies; in contrast, only three $\mathrm{e}^{10,17,18}(50.0 \%)$ studies were considered adequate satisfactory in the definition and validation of the diagnosis of periodontitis. Only one study ${ }^{18}(16.67 \%)$ did not perform statistical adjustment for losses to followup, and three $(50.0 \%)$ studies ${ }^{10,15,17}$ reported losses to follow-up of less than $20 \%$ of the participants.

Publication bias was not evaluated due to the limited number of studies.

\section{Discussion}

The present systematic review with meta-analysis showed an association between periodontitis and MI, but with high heterogeneity.

The results obtained in this study corroborate the hypothesis that chronic inflammation is involved in the pathogenesis of the atherosclerotic process and in triggering acute ischemic events. ${ }^{19}$ Previous studies have demonstrated that infectious agents are capable of inducing local and systemic inflammatory mechanisms. In response to pathogens, reactive oxygen and lipoprotein species are released, leading to the recruitment and proliferation of inflammatory cells such as $\mathrm{T}$ lymphocytes and macrophages. ${ }^{20}$ Infection stimulates the release of cytokines (Il-1 beta and TNFalpha) by the periodontal vascular complex or coronary endothelial cells, promoting platelet aggregation and thrombus formation. ${ }^{20,21}$

The present study has several limitations. Most of the included studies classified the outcome and exposure according to medical records or selfreports. Only three ${ }^{10,17,18}$ studies used standardized diagnostic methods for periodontitis, and none used standardized methods to define MI. This variability in the definition criteria of periodontitis and MI may be one of the causes of the great heterogeneity identified in the studies. Another factor is the reduced number of well-structured studies, and the long period between the studies, which compromises the reliability of this meta-analysis. Despite that, the search strategy was broad and included the most relevant evidence available.

The results of this systematic review and metaanalysis suggest an association between periodontitis and an increased risk of MI. The heterogeneity identified between the studies suggests the need for more studies that include the assessment of these factors in a more standardized manner and longer follow-up period to support a causal relationship.

\section{Potential Conflict of Interest}

No potential conflict of interest relevant to this article was reported.

\section{Sources of Funding}

There were no external funding sources for this study.

\section{Study Association}

This study is not associated with any thesis or dissertation work.

\section{Author contributions}

Conception and design of the research: Baptista $\mathrm{AH}$, Bodanese L, Salum FG, Mattiello R. Acquisition of data: Louzeiro GC, Magnus GA. Analysis and interpretation of the data: Louzeiro GC, Magnus GA, Bodanese L, Salum FG, Mattiello R. Statistical analysis: Mattiello R. Writing of the manuscript: Louzeiro GC, Magnus GA. Critical revision of the manuscript for intellectual content: Bodanese L, Baptista AH, Salum FG, Mattiello R. 


\section{References}

1. World Health Organizaton (WHO) . World Health Statistics 2018: Monitoring Health for the SDGs. Geneva: WHO; 2018.

2. Novikova OA, Laktionov PP, Karpenko AA. Mechanisms underlying atheroma induction: the roles of mechanotransduction, vascular wall cells, and blood cells. Ann Vasc Surg. 2018 Nov;53:224-33.

3. Rifai M, Cainzos-Achirica M, Blaha MJ, Arps K, Wood DA, Blumenthal RS, et al. Health factors associated with cardiovascular wellness. Curr Atheroscler Rep. 2019;21(10):1-7.

4. Almeida APCPSC, Fagundes NCF, Maia LC, Lima RR. Is there an association between periodontitis and atherosclerosis in adults? a systematic review. Curr Vasc Pharmacol. 2018;16(6):569-82.

5. Tonetti MS, Greenwell H, Kornman KS. Staging and grading of periodontitis: framework and proposal of a new classification and case definition. J Periodontol. 2018;89(S1):S159-72.

6. Aarabi G, Heydecke G, Seedorf U. Roles of oral infections in the pathomechanism of atherosclerosis. Int J Mol Sci. 2018;19(7):1978.

7. Liljestrand JM, Paju S, Buhlin K, Persson GR, Sarna S, Nieminen MS, et al. Lipopolysaccharide, a possible molecular mediator between periodontitis and coronary artery disease. J Clin Periodontol. 2017;44(8):784-92.

8. Brasil. Ministério da Saúde. Projeto SB Brasil 2010. Pesquisa Nacional de Saúde Bucal: resultados principais. Brasília, DF: 2012.

9. Lockhart PB, Bolger AF, Papapanou PN, Osinbowale O, Trevisan M, Levison $\mathrm{ME}$, et al. Periodontal disease and atherosclerotic vascular disease: does the evidence support an independent association?: a scientific statement from the American Heart Association. Circulation. 2012:125(20):2520-44.

10. Arbes SJ, Slade GD, Beck JD. Association between extent of periodontal attachment loss and self-reported history of heart attack: an analysis of NHANES III data. J Dent Res. 1999;78(12):1777-82.

11. Kebschull M, Demmer RT, Papapanou PN. “Gum bug, leave my heart alone!"-epidemiologic and mechanistic evidence linking periodontal infections and atherosclerosis. J Dent Res. 2010;89(9):879-902.
12. Rydén L, Buhlin K, Ekstrand E, Faire U, Gustafsson A, Holmer J, et al. Periodontitis increases the risk of a first myocardial infarction: a report from the PAROKRANK study. Circulation. 2016;133(6):576-83.

13. US Department of Health and Human Services. Assessing Cardiovascular Risk: systematic evidence review from the risk assessment work group, 2013. Seattle: NIH; 2013.

14. Noguchi S, Toyokawa S, Miyoshi Y, Suyama Y, Inoue K, Kobayashi $Y$. Five-year follow-up study of the association between periodontal disease and myocardial infarction among Japanese male workers: MY Health Up Study, J Public Heal. (United Kingdom). 2015;37(4):605-11.

15. Lee JH, Lee JS, Park JY, Choi JK, Kim DW, Kim YT, et al. Association of lifestyle-related comorbidities with periodontitis: a nationwide cohort study in Korea. Med. (United States). 2015;94(37):e1567.

16. Hansen GM, Egeberg A, Holmstrup P, Hansen PR. Relation of periodontitis to risk of cardiovascular and all-cause mortality (from a Danish Nationwide Cohort Study). Am J Cardiol. 2016;118(4):489-93.

17. Holmlund A, Lampa E, Lind L. Oral health and cardiovascular disease risk in a cohort of periodontitis patients. Atherosclerosis. 2017 July;262:101-6.

18. Holmlund A, Holm G, Lind L. Severity of periodontal disease and number of remaining teeth are related to the prevalence of myocardial infarction and hypertension in a study based on 4,254 subjects. J Periodontol. 2006;77(7):1173-8

19. Szmitko PE, Wang CH, Weisel RD, Almeida JR, Anderson TJ, Verma $\mathrm{S}$. New markers of inflammation and endothelial cell activation part I. Circulation. 2003;108(16):1917-23.

20. Muhlestein JB, Anderson JL. Infectious serology and atherosclerosis: how burdensome is the risk? Circulation. 2003;107(2):220-2.

21. Emingil G, Buduneli E, Aliyev A, Akilli A, Atilla G. Association between periodontal disease and acute myocardial infarction. J Periodontol. 2000;71(12):1882-6

\section{*Supplemental Materials}

For additional information, please click here. 